\title{
A Concept of Nature in the Modern Animalistic Art of Russia: An Environmental Aspect of the Genre
}

\author{
Irina Portnova ${ }^{\dagger}$
}

\section{Abstract}

The study deals with the concept of nature in modern local wildlife art from the perspective of environmental thinking. It is significant in both cultural and artistic aspects. Modern wildlife art has become a vehicle for pressing issues in nature studies and has demonstrated a variety of artistic solutions, creative manners, and approaches, from traditional realistic variants to stylistic interpretations in the spirit of previous epochs. The study reports that the passage of time has caused changes in the historically established genre structure; its boundaries have become vague and the very structure of an artistic image has become polysemic. Nowadays, local art criticism does not cover this issue adequately.

Meanwhile, modern wildlife art represents a bright example of the thematic and stylistic variety of artistic techniques and has a fresh look at the world of animals in its entirety, which refers to a new perception of nature, human attitude to it and supplements the picture of the development of the entire local arts. Against this background, the study of current wildlife issues is quite relevant. The historical and artistic methods allow us to evaluate the originality of animalism, its different sides, in particular genre, species and stylistic diversity, as a characteristic and an iconic phenomenon of modern art, reflecting the concept of "nature" in its ecological perspective. The significance of wildlife art is stressed in moral respect. It is wildlife art, which is closest to nature that organically reflects the picture of the modern world with its current environmental issues and dire ecological situation. The wildlife art of the end of the 19th Century to the beginning of the 21st Century is characterised by the exploration of new vital issues of its time. Therefore, the material given in the article is important for art criticism since it enriches it with a unique perspective of study and in a wider cultural meaning, and, thus, forms a modern philosophical picture of human-nature-animals interrelations.

Keywords: Animals; Ecology; Moral Aspect; Image; School; Realism; Trend; Style; Artistic Worldview

\footnotetext{
' Peoples' Friendship University of Russia), Moscow, Russia. Moscow, the project "5-100"

E-mail: irinaportnova@mail.ru

(C) 2020 Portnova. This is an Open Access article distributed under the terms of the Creative Commons Attribution License (http://creativecommons.org/licenses/by/2.0), which permits unrestricted use, distribution, and reproduction in any medium, provided the original work is properly cited.
} 


\section{Introduction}

Since its formation in the 18th Century, the animalistic genre has directly reflected the idea of wildlife. This process was observed at all historical stages of its development and unlike other genres, animalism reflected it most vividly. From the 18th Century to the 19th Century there was a strong interest in the material world and nature. At the end of the 20th Century, the theme of nature was often perceived as ecological. This perspective determines the novelty of this study and its relevance. The analysis of the laws of development of animalism and its stylistic features in the context of time dictated the purpose of the study, whose aim was the portrayal of an animalistic image as a model of new art; the new "concept" of nature lies in the field of ecology, and a way of further developing animalism.

\section{Degree of Elaboration of the Issue: Local Experience}

Since the 1920-1950s, the art of local wildlife has been covered in general studies, books, collections, magazines, and catalogues, which characterise it as a quite fruitful art form. In the 1970-1980s, due to the change of development in wildlife art, there emerged a large number of publications, which dealt with social and moral issues. Panhuman and philosophical themes became more popular. These tendencies have equally covered all kinds of art: painting, graphics, sculpture, and decorative-applied art. At that time, the articles about the creative works of S.I. Aseryantz (Veselitskaya-Ignatus, 1986:74-83),D.V.Gorlov(Kramarenko,1965:77-

94, Tikhanova, 1968: 34-37), L.T. Gadaev (Yablonskaya, 1979: 142-148), P.M. Kozhin (Bubnova, 1978: 189-192, Andreeva,1987: 223237), A.G. Sotnikova (Makarov, 1976: 4345,Perfiliev,1979: 295-300, Murina, 1984: 21), A.M. Belashov (Svetlov, 1972: 24-29 ), M.G. Ostrovskaya (Granovskaya, 1976:.31), A.V. Marz (Kelman, 1973: 35-37), I.G. Frikh-Khara (Slonim,1972:18-20) and others were published. Large exhibition activities of that time conditioned the publication of these articles.
Animalists participated actively in regional and national exhibitions linked to various themes.

The 1990-2000s were marked by a stronger perception of wildlife that opened the door to the analysis of the heritage of wildlife artists. In this respect, we can note V.A. Tikhanova's publications (Tikhanova, 1979-80: 373-376) are crucial because they tackle issues closely associated with the moral and ethical assessment derived from the very essence of a wildlife artist. By observing the various methods and techniques used by 20th Century artists, there is a clear-cut concept of wildlife conservation juxtaposed at the core of wildlife art in the modern age. In general, a clear representation of the viewpoints of the researchers on wild fauna and the visual arts reveals their system of values and ideals, which prove to be quite relevant in the epoch of tackling global ecological issues.

International experience. Wildlife art was also a subject of interest to scholars/artists living across the globe. Researchers were eager to cover the history of ancient and classical European animalistic art (Aftandilian, 2007:343, Diana Craig Patch, 2001: 275, Morphy, 2014: 508). Like local authors, they discussed the significance of wildlife art of ancient civilisations and the role played by animals in society and stressed the necessity to study this art and the ways to depict animals (Doug Lindstrand, 2006: 143, Amberlyn, 2012: 192, Hugh Laidman, 2012: 160). In the modern era, the international scholars are likely to view through the lens of certain postmodern theories using various constructivist variants, which can represent an animal; however, their role in the life of the modern world is not diminished. Steve Baker in his book The Postmodern Animal wrote about it (Baker, 2000: 207). Analysing the creation of American painter Mark Dion, and the British Olly Williams and Suzi Winstanley, as well as Henry Moore, the scholar refers to a philosophical pattern in their art, which treats animals as carriers of ideas of postmodernism that were popular in literature and art in the 1990s. A current idea- the concept of natural world 
conservation, which became universal and represented a necessary conglomerate of human activities - was embodied in the works of both local and international scholars/artists . It added a new layer to the value of the natural world including wildlife art. Accounting for the contrasts of modern artistic vision, when an image of an animal is portrayed unusually, varying from its real-life counterpart or, in a modified form, ranging from the latest installations inspired by the ideas of modern literature and theatre and often the styles of previous epochs, the scholars try to justify the existence of such projects-images. Offering ideas on how necessary it is to protect crucial natural spaces, which became incredibly unstable during the climate crisis and other issues that dominate their ideology.

The existing literary experience of the art historians suggests that we need to continue the discussion about modern local wildlife art from the perspective of its main concept. The existing literature shows that some experience has been accumulated opening the possibilities of understanding and studying wildlife art at the end of the 20th Century to the beginning of the 21st Century in its crucial areas. As shown by the analysis of historiography, these issues have not received much attention and were somewhat divided. In this respect, the publications of V.A. Tikhanova, M.N. Yablonskaya, E.V. Bubnova referring to the creative works of D. Gorlov, A. Sotnikov and L. Gadaev and other masters are of some interest, since they enable us to trace the criteria of assessing the creative works of masters on wildlife art and their outlook on animalism, thereby stimulating a deeper understanding of the specifics of the genre itself.

\section{Methods}

The method of art analysis is identified as the most reasonable in addressing these issues. It implies two levels of study: historicalproblematic (with the setting of modern animalistic aspects) and historical-artistic, which enables us to analyse the general direction of the development of wildlife art of the end of the 20th Century to the beginning of the 21st
Century mostly in a stylistic-imagery aspect. It enables us to reveal the peculiarities and originality of an artistic image, its structure, and distinctive features of a pictorial language more clearly and to see the dynamics of the genre itself, the quality of an animalistic image concerning the general direction of the epoch in a historical perspective. This study presents the reference in a historical-cultural method, which enables in defining the place of wildlife art as a specific artistic phenomenon in the history of domestic art.

As a result, the interaction of these approaches makes it possible to explore the environmental issues of the animalistic art of the late 20thearly 21st Century as part of the overall problems of fine art in a period.

\section{Osobennosti Animalis Ticheskogo Zhanra: Results and Discussion}

The life of an individual in society and its place in the universe, as well as its understanding of the natural environment, has been the subject of many philosophical doctrines starting from ancient times until now. Thus, the natural philosophy of the 18th Century reflected a new sphere of natural being. One can refer to an exciting area, which became widespread in Russia - drawing live "naturelles" from the Kunstkamera's samples reflected in a so-called "Kunstkamera" drawing. Admiration of the beauty and peculiarity of nature and its objects formed the worldview of an artist including the assessment of properties, proportions, and the scale of objects in their entirety as they exist in harmony. Then, the admiration of nature became apparent in the paintings devoted to animals. The 19th Century displayed new priorities in the field of wildlife art. The equine genre (depiction of a horse) became prominent. It demonstrated the artistic criteria of wildlife art and its significance not only for particular social circles (connoisseurs and lovers of horses) but, more broadly, as moral art, which forms an appropriate approach to a certain animal. A distinctive "horse culture" became a symbol of that time. This universal process was also a characteristic of Western art as it had its traditions and national peculiarities from Russia. 
These traits were manifested in the choice of a character. The image of Orlov Trotter, who became the national pride of Russian society, and the poetisation of a peasant horse in painting and classic literature reflected its unique characteristic qualities. Besides, the depiction of a favorite character distant from the idealisation of the Western samples showed the advantages of Russian realistic paintings (Figure 1)

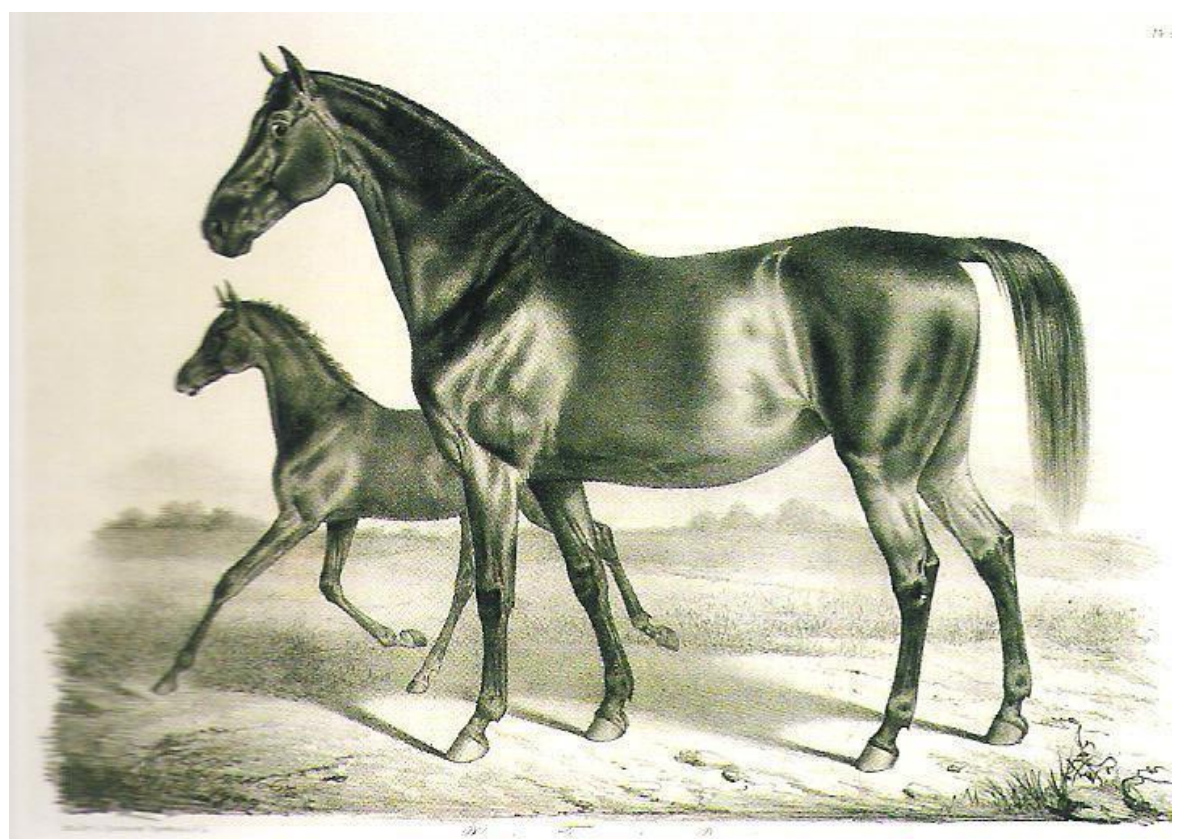

Figure 1: N.Sverchkov. Germany Khrenovskogo Plant. Source: Lithography, 1832-1845

The end of the 19th Century to the beginning of the 20th Century became a new stage in all respects. Nature became more inspired by human thinking and is attributed to intimate traits. Thus, the simplicity of landscapes and depicted animals have their understanding of a habitable world directly associated with human activities. This was a hymn of beauty in its poetic perception.

During the first half of the 20th Century, the state of affairs in nature and wildlife art changed. First, that time was marked by an unprecedented boom of natural sciences including branches of biology such as ethology, animal psychology, genetics, and physiology, which study animals from a new perspective. The actualisation of animalistic art was associated with the social environment, mostly scientific, demonstrated more and more interest in the animal world and wildlife in general. The organisation of an artistic workshop within the walls of the Darwin Museum in Moscow initiated by a wildlife artist V.A. Vatagin - already famous by that time- contributed to the first creative experiences in the area of wildlife art. Then, the Moscow school of wildlife art was established at the height of scientific thinking and social enthusiasm (Figures 2 and 3). 


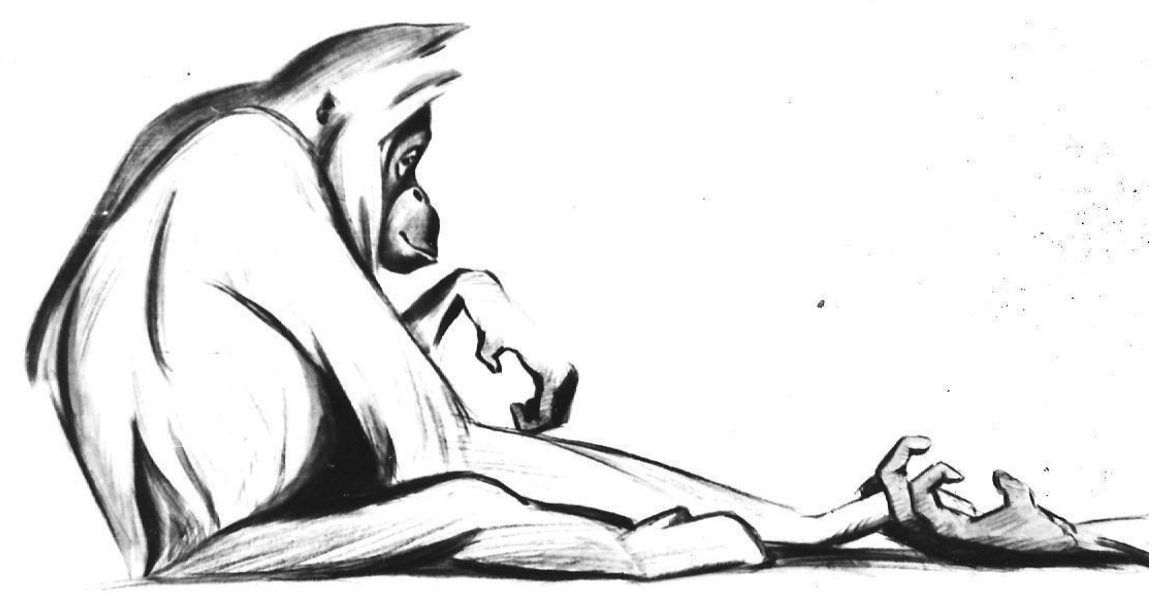

Figure 2: V.Vatagin. Handshake. 1926. Pencil. Source: State Darwin Museum (GDM), Moscow

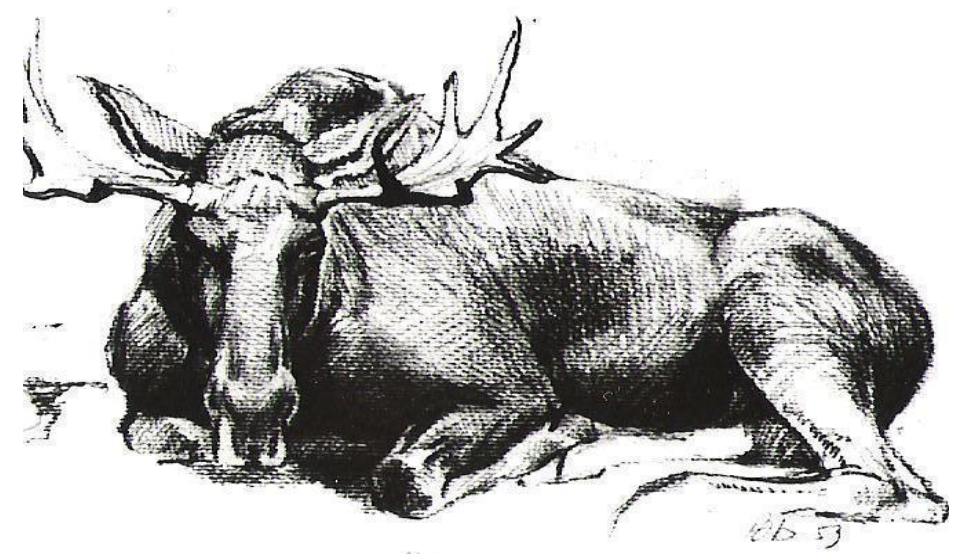

Figure 3: V.Belyshev. Moose. 1953. Pencil Source: State Darwin Museum (GDM) Moscow

In the Moscow school of wildlife art, the major figures in wildlife art appeared-the first by V.A. Vatagin and I.S. Efimov, followed by A. Sotnikov, S. Churakov, A. Kardashev, P. Kozhin, and P. Balandin, who established essential trends in this genre of art. Later, A.M. Belashov, A.S. Tsvetkov, O.V. Malysheva, S.I. Aseryants, G.N. Popandopulo, P.S. Kirillova, O.A. Kulikova, A.V. Marts, N.F. Fokin, E.V. Nikolaev etc. built a name for themselves (Figures 4 and 5). This process was most fruitful in Moscow, which had become the centre of development for this genre.

Second, starting from the second half of the 20th Century when wildlife art had entered a new path of development, the study of the environment and animals revealed significant issues regarding their state (environmental issues). The full picture of nature was finally seen. And it was animalists who declared this challenge. Thus, V.A. Vatagin expressed his opinion on this issue in the pages of his memoir-Memoires: A Wildlife Artist's Note.s He wrote, "No animal will torture or kill its victim in vain. However, how cruel and sometimes destroying a human is to animals! What huge bloody count nature could claim to a human for many annihilated beautiful species of animals created by it!" (Vatagin, 1980:7). In this respect, D. Gorlov's statement is representative. In his letter to Vatagin, he admits, "I need to deal with my beloved animals and birds to become a human (...). An animal is much more generous, 
sincere and less cunning than a human" (Gorlov's letters to V.A. Vatagin, 1960-1968: 107). B. Vorobyev's words show empathy with wildlife and where it is going:

[t]he destiny of all national parks seems miserable (...). I am afraid many species of creatures will be destroyed as early as in this century. What a poor heritage we leave to our generations! There will be less and less people close to nature and seeking for true inspiration and consolation in it; indeed, many material "benefits" acquired by humanity cannot repair losses inflicted on the world by these acquisitions, since it is not souls but rather stomachs that acquire(Vorobyev's letter to V.A. Vatagin, 1959-1960: 103).

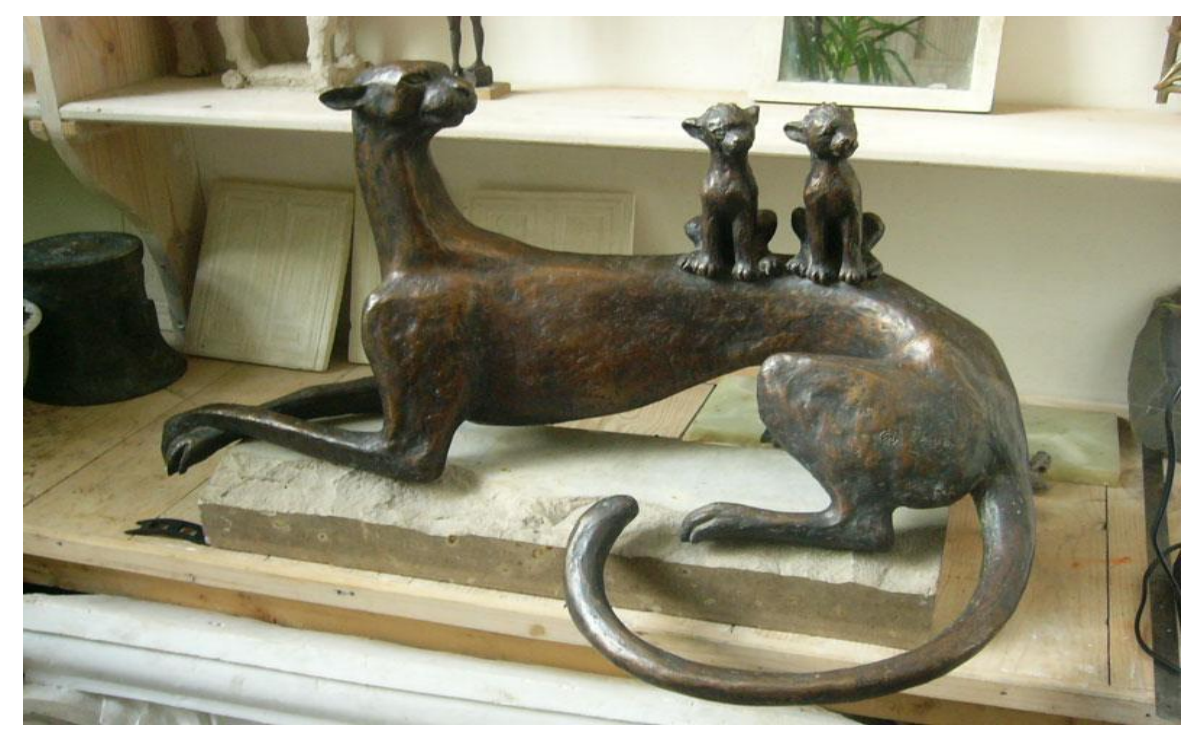

Figure 4: M. Ostrovskaya. Cheetah, Bronze, 1990s

Source: State Tretyakov Gallery (GTG). Moscow

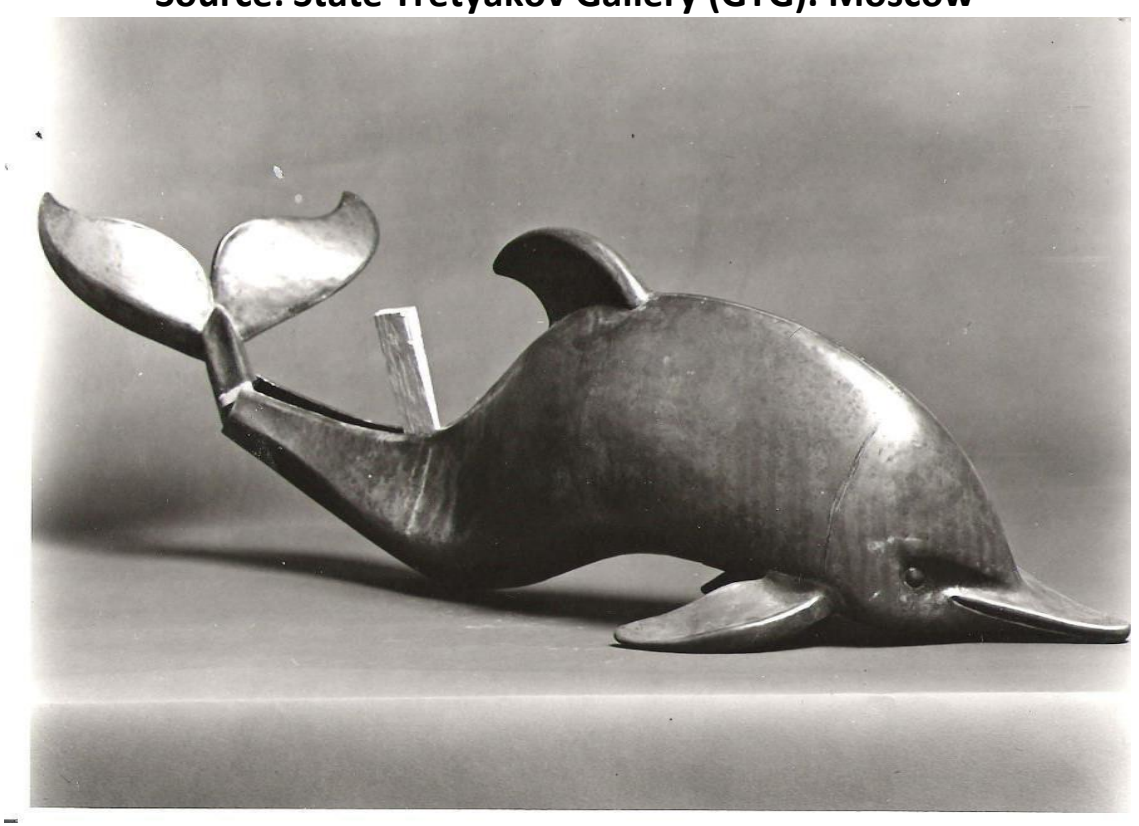

Figure: 5 I. Yefimov. Dolphin. Wrought copper. Source: State Tretyakov Gallery (GTG), 1935, Moscow

Personality and feelings become inseparable from the concept of the world and nature, both philosophically and aesthetically. M.N. Enstein rightfully assumed that "if zoocentrism is an initial, historically irrelevant stage of cultural development, animalism plays an increasing role 
in the creation of prerequisites for ecologically balanced culture" (Enstein, 1986:126-146). Earlier, an animal was shown in its concrete, life image that stressed its character; however, in the second half of the 20th Century, it was understood better, as an inseparable and integral part of the world order. Indeed, the environment and the microclimate became a central subject of cultural analysis. In the establishment of new artistic integrity and the solution to current issues, wildlife art became publicised and a carrier of moral and ethical issues. This is shown by the very existence of frequent expositions of wildlife sculptures and graphics and their participation in mixed exhibitions. A broad panorama of wildlife exhibitions enables us to define the picture of the development of the genre at the end of the 20th Century. Thus, the mastering of new (sometimes challenging) themes including the depiction of an animal under the sign of tragedy and drama of wildlife (V. Klykov, G. Popandopulo, V. Gubko, L. Gadaev, G. Glyziana, L. Nesterovich) became a prominent feature of that time. An animal acts as a major valid idea in the global concept of conserving the terrestrial world. The issues of the time, which needs to be solved by new means caused the changes in the structure of the genre.

The first sign is genre-typological. Modern artistic thinking of combining the traits of various kinds of art gave a more intensive psychological analysis of the wildlife, animals, and human relations in it. Contemporary wildlife art sees the transformation of forms and rejects similar styles of genres of that period. Accepting the development of all kinds of paintings and acknowledging them as equal is associated with the universalism of modern artistic culture. It is far from either pursuit of narrow specialisation or the idea of strict division into genres. The second sign- genre-stylistic movement is characterised by a variety of forms. On the one hand, this is determined by a pursuit of the direct expression of an artist's thought. On the other hand, pursuit of approaching the personage, the direct expression, or both things merge in a complex narratively compositional intertwining.
At exhibitions, it is often seen works marked by the search for non-traditional formation of an artistic image. Animals are portrayed in cities, an everyday human sphere and become the participants of its prosaic everyday routine and, at the same time, they are poetised. New themes and motifs-the form of avant-garde used by artists enlarge the sphere of plastic thinking, produce new expressive means and techniques, and expand the boundaries of a traditional image. A modern artist avoids singlevalue estimates. We see a similar process in wildlife art, which is also marked by the traits of dialogue. In this respect, one of the dominant aspects of a modern world is a revival of interest in creative mastery. When an artist refers to the past, he inevitably faces a challenge of presenting this past to a modern-day audience that lacks spiritual understanding and emotional perception. This environment and this microclimate become a central subject of the artistic analysis of many works of animal painters. The coincidence of two viewpointsfrom history to the present time defined the compositional arrangement of the works and their internal logic. Wildlife art is elaborated via various stylistic trends and merges the potentials of several types and genres of art, from ancient epochs to "men of the sixties and seventies" and a subsequent period to give a more intensive analysis of the world, nature and human relations in it.

We can identify "neo-baroque" strivings enriched by new tendencies of "natural style" (A. Belashov, M. Ostrovskaya, A. Marz, O. Malysheva, S. Aseryantz, V. Gubina, V. Sidorov, N. Bogushevskaya), reminiscences of popular art (L. Berlin, A. Petinat, N. Sazykina, T. Chebotareva, M. Kalmykova, V. Dobrokhotova, V. Tsoi, N. Gonchar), traits of "design-style" and constructivist portrayal of an image (V. Sokolov, D. Voronin, P. Khohlovkin, G. Bagdasaryan, I. Rukavishnikov, O. Ryashentsev, R. Sherifzyanov), and archaic tendencies (V. Klykov, V. Tsigal, A. Anistratov, L. Gadaev, V. Gubko).

In general, from the viewpoint of modern perception, retrospection is read in one meaning - to raise the significance of a true motive to 
panhuman height. The boundaries of the animalistic genre as it had been in the 19th Century to the first half of the 20th Century lost their currency in modern art. The process, which had been already observed in the middle of the 20th Century, acquired sustainable manifestation in the second half of the 20th Century and until now. This general tendency is typical for local pictorial art from the end of the 20th Century and the beginning of the 21st is understood in wildlife art as many-aspects acquiring the world of nature in both its variety and integrity.

\section{Conclusion}

The study aimed at examining the concept of nature in modern local wildlife art from the perspective of environmental thinking. To accomplish the objective, the study used important materials for art criticism since it enriches it with a new unique perspective embedded in a wider cultural meaning, and, thus, forms a modern philosophical picture of human-nature-animals interrelations. It is arguable that if one refers to a general historicalartistic process of the New Time, in which domestic wildlife art existed, we can conclude that its role was defined by a genre capable of recreating all the plenitude of the natural world associated in a broad sense with a "worldview". In the 20th Century, understanding the "picture of the world" became inseparable from addressing environmental issues. In this way, animalism, having had a role in the independent genre quality and different types of fine arts, played an integral part. It was able to solve complex modern problems in the most critical areas. The sphere of relations between nature and man. The views and judgments of the animal artists themselves showed how important this conversation is. The animalistic character, who appeared in different stylistic versions, clearly demonstrated the possibilities of the genre, the breadth of coverage of this problem.

All this has enabled us to assess modern domestic wildlife art as a character structural pictorial phenomenon of the time, within a framework of which wildlife art in general
European context is considered special and is produced by national peculiarities of the Russian culture.

\section{References}

Aftandilian, D. (2007). What are the Animals to Us?: Approaches from Science, Religion, Folklore, Literature, and Art, pp.343.

Amberlyn J. C (2012). The Artist's Guide to Drawing Realistic Animals How to Draw Cats, Dogs, and Other Favorite Pets. Watson-Guptill Publications, pp. 192.

Andreeva L.M. (1987). Kozhin. Sovetskoe Dekorativnoe Iskusstvo 9. Moscow, pp. 223237.

Baker S. (2000). The Postmodern Animal. Reaktion Books, pp.207.

Bubnova E.A. (1978). Pavel Mikhailovich Kozhin. 1909-1975. Sovestkaya Skulptura 76. Moscow. Sov. Khudozhnik, pp.189-192.

Craig Patch D, Eaton-Krauss M, Susan J. Allen (2011). Dawn of Egyptian Art, Metropolitan Museum of Art, pp. 275.

Granovskaya N. (1976). Marina Ostrovskaya. Dekorativnoe Iskusstvo SSSR. 1, pp. 31.

Gordon Lindsay Campbell. (2014). The Oxford Handbook of Animals in Classical Thought and Life, pp. 633.

Gorlov's letters to. Vatagin V.A. (1960-1968). Russian State Archive of Literature and Art F.3022, op.1, ed. khr. 107.

Enstein M.N. (1986). Mir Zhivitnyh i Samopoznanir Cheloveka. World of Animals and Human Self-Cognition (Following the Russian XIX-XX Centuries Poetry).

Kelman L. (1973). Andrey Marz, Animalist Dekorativnoe Iskusstvo 7, pp. 35-37.

Kramarenko L.G. (1965). Gorlovskie Zveri Khudozhniki Veschei, pp.77-94.

Laidman H. (2012). Drawing Animals, Courier Corporation, pp.160.

Lindstrand D. (2006). The Artist's Guide. North Light Books, p. 143 
Makarov K. (1976). Bolshaya Ptitsa Alekseya Sotnikova (k 70-letiyu so dnya rozhdeniya skukptora) Dekorativnoe Iskusstvo SSSR 1. pp.43-45.

Murina E. A. (1984). Sotnikov.

Vesna Dekorativnoe Iskusstvo SSSR 1. pp. 21.

Morphy H. (2014). Animals Into Art. pp. 508.

PerfilievV.(1979). Aleksei Georgievich Sotbikov. Sovetskaya Skulptura. 77. pp. 295-300.

Slonim I. (1972). Chem Khorosh Frikh-Khar (k 80-letity khudozhnika). Dekorativnoe Iskusstvo SSSR 9. pp. 18-20.

Svetlov I.E. (1972). Vdokhnovlyayuschaya Sila Prirody. Iz Masterskoy Skulptora Belashova Iskusstvo 10. pp. 24-29.
Tikhanova V.A. (1979). Russian Animalists. Sovetskaya Grafika. pp. 373-376.

Tikhanova V.A (1990). Animalistika. Granitsy Zhanra Ocherki o Sovetskih SkulptorahAnimalistah Sovetskiy Khudozhnik, pp.240 .

Tikhanova V.A. (1968). Skulptor-Animalist D.V. Gorlov Iskusstvo. 3, pp.34-37.

Vatagin V.A. (1980). Vospominaniya. Zapiski Animalista. Articles, pp.7.

Veselitskaya-Ignatus (1986). N. Svetlana Aseryantz. Sovestkaya Skulptura 10, pp. 74-83.

Vorobyev's letter to V.A. Vatagin (1959-1960). Russian State Archive of Literature and Art. F.3022, op.1, ed. khr. 103.

Yablonskaya M.N.(1979). Skulptor Lazar Gadaev Sovestkaya Skulptura 77, pp. 142-148 